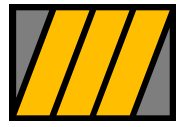

ESCUELA DE NEGOCIOS Universidad Torcuato Di Tella

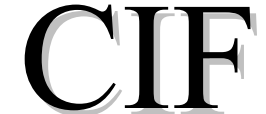

Centro de Investigación en Finanzas

Documento de Trabajo 08/2003

\title{
Financial Dedollarization: A Carrot and Stick Approach
}

Eduardo Levy Yeyati

Universidad Torcuato Di Tella
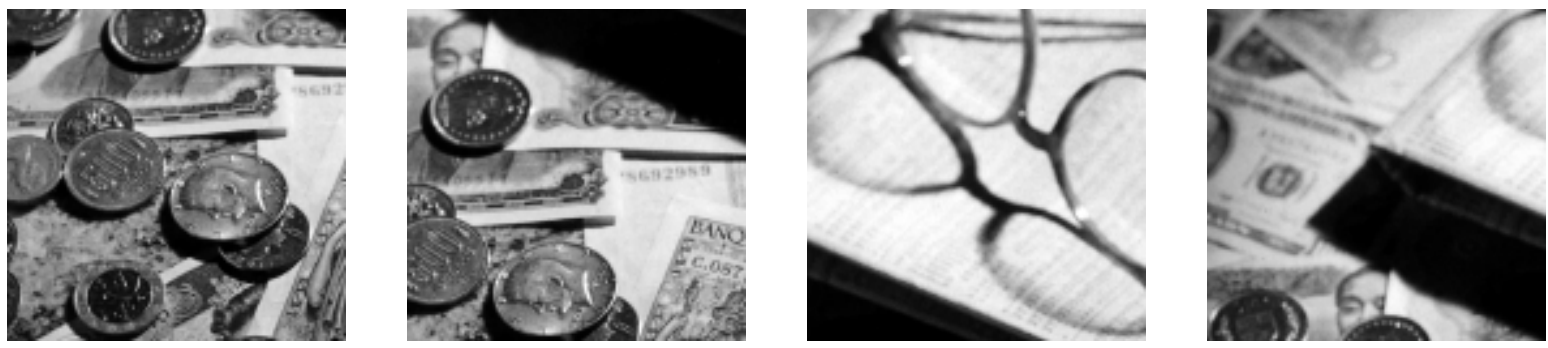

Miñones 2177, C1428ATG Buenos Aires • Tel: 4784.0080 interno 181 y 4787.9394 - Web site: www.utdt.edu/departamentos/empresarial/cif/cif.htm 


\title{
FinANCial Dedollarization:
}

\section{A Research Agenda}

\author{
Eduardo Levy Yeyati ${ }^{1}$ \\ Universidad Torcuato Di Tella
}

February 14, 2003

[Very preliminary. Comments welcome.]

\footnotetext{
${ }^{1}$ The author wish to thank Eduardo Fernández Arias for his encouragement and invaluable suggestions, Eduardo Morón and Jose Licandro for their helpful comments and the IDB for financial support. All disclaimers apply.
} 


\section{Introduction}

Most of the earlier literature on de facto dollarization was concerned with currency substitution, as reflected by its focus on the dynamics of money demand (and, in particular, the link between dollarization and inflation) with a view to its monetary policy implications. The focus on currency substitution also seems to underlie the presumption, usually subscribed by this literature, that dollarization should recede with price stability. ${ }^{2}$

This presumption was visible at odds with the reality of the 90s: In most cases, dollarization levels remained high or even increased after inflation levels declined. ${ }^{3}$ This, combined with the fact that, as noted by many observers, much of the previous empirical literature faced a definitional conundrum (as money demand equations were estimated based on interest bearing deposits that generally account for the bulk of measured dollarization), ${ }^{4}$ shifted the focus of the debate from currency substitution to asset substitution or, more precisely, financial dollarization.

Some definitions are in order at this stage. Here, following the conventions in the literature, currency substitution refers to the use of a foreign currency as a means of payment or unit of account, whereas asset substitution denotes its use as a store of value. Financial dollarization, in turn, simply denotes an empirical observation, namely, the holding by residents of foreign currency-denominated assets and liabilities (including non-bank assets such as commercial paper or sovereign debt). While descriptive in nature, the definition implicitly assumes that the currency composition of residents and non-residents should differ, with the former more prone to invest in local currency assets

\footnotetext{
${ }^{2}$ The literature on de facto dollarization is too extensive to be summarized here. Recent surveys can be found in Calvo and Vegh (1992 and 1997), Giovannini and Turtleboom (1994), and Savastano (1996), and Baliño et al. (1999).

${ }^{3}$ Explanations of dollarization persistence (referred to in the literature also as "hysteresis") typically hinge on lack of credibility (e.g., the presence of large inflationary memory, as in Savastano, 1996) or network externalities (e.g., the costs of switching the currency of denomination of everyday transactions, as in Guidotti and Rodriguez, 1992). Both arguments, again, are consistent with a view of dollarization as a currency substitution phenomenon.

${ }^{4}$ Calvo and Vegh (1992) already make this point.
} 
than the latter. As such, it is centered on the inability of certain countries to develop deep local currency markets. Moreover, the definition highlight the difference with the concept of "original sin", which denotes the inability to borrow in domestic currency internationally, which, unsurprisingly, tends to focus on non-residents' unwillingness to lend in the borrower's currency. ${ }^{5}$

There are many reasons why financial dollarization should be put at the forefront of the policy debate. First, inasmuch as financial dollarization influences the pricing behavior of firms and individuals, dollarized economies are induced to limit wide fluctuations in the nominal exchange rate due to their deleterious impact on inflation performance. As Chang and Velasco (2000) point out, "any scheme to control the rate of inflation at a short horizon must control, to some extent, the nominal exchange rate."

Moreover, and more to the point of the proposed agenda, while some dollarization may be warranted as a hedge exchange rate risk of tradable producers, widespread financial dollarization inevitably introduces a currency imbalance for the economy as a whole (either at the banks' balance sheets through local currency on-lending, or through increased credit risk of dollar-indebted producers of non-tradables, including the public sector), a concern that has been flagged by most of the recent financial crises. ${ }^{6}$

More precisely, a real exchange rate adjustment due to an adverse external shocks reduces the capacity to pay of foreign currency debtors (alternatively, its leverage ratio), amplifying the real impact of the shock. At the micro level, if the exchange rate or the domestic prices are free to adjust, the balance sheet effect is limited to producers of nontradables that suffer the relative price adjustment, and to the public sector inasmuch as its revenue is proportional to largely non-tradable product. If the exchange rate is fixed and

\footnotetext{
${ }^{5}$ See, e.g., Eichengreen, Haussmann and Panizza (2002). By international (or external) debt we refer to debt issued under international (as opposed to local) Law. Thus, debt issued under New York Law would be external if issued by Germany but domestic is issued by the U.S.

${ }^{6}$ The few papers that address the issue of financial dollarization from an empirical perspective (Thomas, 1985, Sahay and Vegh, 1997) understate the fact that deposit dollarization is typically accompanied by loan dollarization, due to standard prudential limits on balance sheet foreign currency positions, a factor that certainly plays a role in the extent of financial dollarization and its prudential implications. An exception in this regard is Ize and Levy Yeyati (1998).
} 
prices are downward inflexible, the effect, while still stronger for non-tradable producers, spills over tradable producers through a protracted quantity adjustment (economic contraction). While this currency imbalance determines the financial system's exposure to large real devaluations as well as the willingness of the monetary authorities to use the exchange rate as a shock absorber, ${ }^{7}$ the authorities' unwillingness to let the real exchange rate fluctuate may in turn foster financial dollarization, as dollar debtors anticipate either a stable real exchange rate or, if this strategy becomes unsustainable, a government bail out. $^{8}$

Similar arguments apply to the dollarization of public debt, that is, the empirical observation that many developing economies denominate public obligations in foreign currencies. While this pattern has been typically attributed to the country's inability to borrow in its own currency, presumably due to the currency's weakness, ${ }^{9}$ one could alternatively argue that the outcome is the result of a deliberate decision, either in order to avoid the cost of a currency risk premium that is judged to be excessive by most governments (e.g., due to an adverse selection problem in which low-inflation governments refuse to pay the cost of a high "peso premium"), or to signal the determination to avoid exchange rate movements, particularly in conjunction with a peg (to mitigate a time inconsistency problem by tying up its hands). ${ }^{10}$

The time inconsistency argument has been modeled by Calvo and Guidotti (1990), who argue that, once the home currency debt is issued, it is optimal for the government's to partially repudiate its obligations by devaluing. Investors anticipate this and require a higher interest rate so that expected returns are comparable to international levels. As a

\footnotetext{
${ }^{7}$ This argument has been proposed by Calvo (2000) and others to account for "fear of floating," that is, the tendency to avoid substantial exchange rate volatility through foreign exchange intervention under formally floating exchange rate regimes.

${ }^{8}$ See, among others, Burnside et al. (1999). Indeed, this implicit guarantee has been at least partially validated in many recent crises (Mexico 1994 and Brazil 1998). Certainly, the forcible pesification of financial assets in Argentina after the collapse of the currency board agreement was an extreme case in which these beliefs were ex-post fully confirmed.

${ }^{9}$ Eichengreen and Haussman (1999) discuss this and other possible reasons.

${ }^{10}$ Alternatively, short-sighted politicians may overstate the short-run costs of reputation building. However, it is not obvious how past actions (reputation) influence rational investors' expectations unless the government exhibits time-invariant characteristics.
} 
result, devaluation (and a higher than optimal inflation rate) occur in equilibrium. Fixed exchange rate regimes provide an extreme illustration of this signaling problem. Since costly domestic currency debt is efficient only as a hedge against exchange rate risk, it immediately signals the government's doubt about the sustainability of the peg, conspiring against the goal of building confidence in the regime. Thus, the dollarization of government debt could be interpreted as a consequence of the stabilizing strategy, and even as a crucial ingredient inasmuch as, by increasing the exchange rate exposure, raises exit costs, creating incentives for the maintenance of the peg. ${ }^{11}$

The time inconsistency argument, however, does not explain the differences across countries. While these differences are often attributed to credibility associated with the country's track record (as, e.g., in Hausmann, 1999), the credibility concept and its underpinnings are still quite elusive. Moreover, a focus on international markets and external debt (as opposed to the domestic demand for local currency-denominated assets) may be misleading. First, most industrial countries blessed with the capacity to issue debt in their own currency do that domestically (that is, under local, rather than international, law). Second, there is a presumption (that begs empirical validation) that their local currency debt (both domestic and external) caters mainly domestic residents. ${ }^{12}$ If so, overcoming financial dollarization would also lead to the expiation of the original sin, which according to this argument will just be another symptom of a weak currency (namely, one that residents do not accept as a store of value). More concretely, the dollarization of developing countries' external debt may be a reflection of their inability to lure domestic savings into local currency debt, that is, the public counterpart of the financial dollarization phenomenon that is the subject of this study.

At any rate, due to the above considerations and a growing consensus that a financially dollarized economy suffers from important external vulnerabilities, the center of the financial dollarization debate appears to be shifting from a generally passive stance (a

\footnotetext{
${ }^{11}$ The argument is developed in De la Torre et al. (2002) to explain the increased dollarization of public debt in Argentina under the currency board agreement.
} 
"learning-to-live-with-it" type of approach, focused on the strengthening of prudential norms or the conduct of monetary policy in both currencies) ${ }^{13}$ to a more proactive one, oriented to limit the incentives that favor dollarization and to foster the development of local currency intermediation. As a result, both heavily dollarized countries and international financial institutions have exhibited of late an interest in measures aimed at dedollarizing the economy, as well as in the experiences of those countries that successfully prevented or reverted financial dollarization, and in those attempted to do so and failed. In particular, due to the prevalence of the dollarization phenomenon in the Latin American countries, the topic has acquired a significant importance in the region.

This agenda, however, is still in its infancy. Previous attempts to dedollarize in many Latin American countries by introducing local-currency indexed deposits, have notoriously failed. On the other hand, countries that avoided dollarization before by discriminating against, or directly banning on-shore dollar deposits have seen off-shore (dollar) intermediation growing. ${ }^{14}$ In addition, Chile remains the only Latin American case in which early indexation prevented financial dollarization. ${ }^{15}$ Moreover, while more open to discussion now than in the early 1990s, financial indexation is still regarded with certain reluctance in policy circles, due to potential spillovers to the real economy and its consequences on inflation inertia. ${ }^{16}$

\footnotetext{
${ }^{12}$ Anecdotal evidence suggests that the little local currency debt issued abroad by industrial countries is held largely by residents, typically due to tax considerations. At any rate, lack of proper information on debt holders is, on this issue, a crucial caveat.

${ }^{13}$ Baliño et al. (1998) is a good example.

${ }^{14}$ Ecuador is a case in point. The run on off-dollar deposits was a crucial factor behind the final move to de jure dollarization.

${ }^{15}$ Brazil's indexation combined with a ban of domestic dollar instruments. In addition, Brazil increasingly dollarized its domestic public debt after the 1998 crisis that led to the devaluation of the real, while dollardenominated foreign borrowing by private sector firms has been on the rise since then.

${ }^{16}$ Indexation of dollar-denominated instruments to a price closely correlated with the debtor's income could attain what could be labeled synthetic dedollarization, that is, delinking the real cash flows of the asset (measured in the local consumption basket) from the evolution of the exchange rate without changing the currency of denomination. While in practice these instruments may be more obscure for the average investor than plain-vanilla CPI-indexed assets and, as such, more difficult to market, they are, on the other hand, free from moral hazard (as the issuer cannot partially repudiate them through high inflation) and thus more attractive for sophisticated investors. By contrast, indexation to some local price like the GDP deflator or a tax revenue index, while still more difficult to market than CPI-indexation, offers no such advantage.
} 
Thus, much more analytical and policy research is needed to assess whether dedollarization should be pursued and, if so, how. Indeed, while analytical arguments that emphasize the presence of market imperfections and risk mispricing suggest that the resulting financial dollarization may be suboptimal, a framework has yet to be developed to make the case that the level of dollarization in particular countries is "excessive", and, if so, to measure the costs of this excess against the potential benefits (most notably, domestic financial deepening) associated with the use of a foreign currency.

The objective of the proposed agenda is to contribute in that direction by exploring the factors underlying the phenomenon, revising the evidence of countries that experimented (with different degrees of success) with measures to foster local currency intermediation, and designing general guidelines as a first step to evaluate the costs and benefits of a dedollarization strategy to orient the policy discussion and, ultimately, inform countryspecific policy measures if such a strategy is advised.

\section{Main analytical issues}

This section summarizes the main analytical issues relevant to understand financial dollarization and to guide dedollarization strategies. After a brief description of the sources of concern identified in the existing literature and the recent policy debate, it lists the questions, most of them still unanswered, that need to be addressed to shed light on the more concrete policy recommendations that are the final objective of this project.

\section{Financial dollarization: Sources of concern}

Interest on de facto dollarization has been motivated basically in two different ways over the years. The earlier literature was primarily concern with its impact on the demand for money and its implications for the conduct of monetary policy, including its implications 
on the stability of money demand and the incidence of currency substitution on the passthrough of exchange rate movements on inflation. ${ }^{17}$

By contrast, the recent focus on financial dollarization have stressed its negative prudential implications. In this regard, the most salient negative by-product of financial dollarization is the inherent real exchange rate (RER) exposure that it induces somewhere in the economy. As frequently noted, this systemic exposure may appear either at the bank level (if foreign currency positions are not limited by regulation) or, more typically, directly at the debtor's level (through the exchange rate risk exposure of dollar indebted non-dollar earners, private or public). In the event of a negative real shock, a fully floating exchange rate adjusts so that the RER achieves its new equilibrium level, reducing the relative price of non-tradables and impinging on the payment capacity of non-tradable producers. The associated balance sheet effects underscore the propensity to limit RER variability by preemptive foreign exchange intervention (Calvo and Reinhart's (2002) "fear of floating"), or directly by fixing the exchange rate. If prices are nominally flexible, however, the presence of a peg does not alter the story, as the RER adjustment comes through deflation, to the same effect. ${ }^{18}$

In a weak currency economy, once financial dollarization exceeds certain threshold, this currency mismatch is inevitable: Residents (and non-residents) prefer to save mainly in a foreign currency and, if this is restricted by the monetary authorities, in short-term local currency assets (inducing a maturity mismatch) or directly off-shore, leading to financial desintermediation. Thus, when financial dollarization is allowed, debtors from the nontradable sector end up with debts denominated in tradables, increasing their exchange rate exposure. On the contrary, when not dollarized, a country with a weak currency displays financial contracts that re-price very frequently (e.g., deposits with interest rates that adjust daily in line with the overnight rate). The third alternative, namely the off-

\footnotetext{
${ }^{17}$ The pass-through effect is still a question of considerable interest, particularly as inflation targeting regimes have come into fashion. It is certainly an issue in low inflation developed countries (see, e.g., Zettelmeyer, 199X) and has been highlighted as a reason behind the observed fear of floating by Calvo and Reinhart (2000).

${ }^{18}$ In practice, instead, price rigidities induce a real contraction that compounds with the deleterious balance sheet effect, and even spills over to the tradable sector.
} 
shorization of domestic intermediation when on-shore dollarization is restricted, again introduces, albeit in a hidden way, a systemic currency mismatch problem. ${ }^{19}$

An additional negative consequence of financial dollarization is its potential impact on the cyclicality of international capital flows. As the previous discussion indicates, negative external shocks tend to increase the leverage ratio of a financially dollarized country's (alternatively, to reduce the country's capacity to pay) as both income flows and assets decline vis à vis debt service. ${ }^{20}$ In turn, given the procyclicality of the capacity to pay, it is not surprising to see that capital flows also behave procyclically, demanding higher returns in bad times, and ultimately reverting once the impact of higher funding costs on the probability of default leads to rationing. In turn, capital flow procyclicality amplifies the real impact of the shocks, conspiring against the possibility of conducting coutercyclical (monetary and fiscal) policies and, by increasing the volatility of returns on financial assets, inhibiting the deepening of long-term markets. By contrast, in a country without financial dollarization, the adjustment to a more depreciated equilibrium RER that comes through nominal depreciation of a flexible exchange rate typically improves (via debt dilution) the capacity to pay, partially offsetting the effect of the economic slowdown. Thus, much of the current discussion on financial globalization and its role in the financial vulnerability of developing economies can be linked to the currency problem reflected in financial dollarization. In this regard, the presence of deep domestic local currency markets could be regarded as a precondition to fully profit from more integrated capital markets. ${ }^{21}$

Countervailing the perils of dollarization discussed above, there are gains provided by a more lenient strategy that allows or even facilitate financial dollarization, primarily its beneficial impact on the deepening of financial markets. While the latter goes hand in

\footnotetext{
${ }^{19}$ De la Torre et al. (2002a) discuss these issues. Argentina is a good example of the first type: In the currency board period, financial dollarization was not only tolerated but also fostered by the authorities. A good example of the second type is Brazil, where not only is dollar intermediation severely restricted but interest rate indexation has been widely used in the past as a "policy crutch" to bolster financial intermediation in the local currency. Pre-crisis Ecuador is an example of the third kind.

${ }^{20}$ While this procyclicality of the debt burden is no different from Fisher's well-known debt deflation effect, its impact is amplifed whenever the adjustment entails a sudden nominal exchange rate change.

${ }^{21}$ See De la Torre et al. (2002b).
} 
hand with the mispricing of risk and the financial vulnerabilities previously discussed (and could even be attributed to them), it could be argued that, in some cases, dollarization is so entrenched that any attempt to reduce it may induce massive desintermediation, with a cost for the real economy that exceeds its long-run benefits in terms of greater financial resilience. Moreover, dedollarization may not be the only way out of the aforementioned prudential concerns, as the latter could be addressed, at least in theory, by alternative means (for example, through indexation of dollar instruments to commodity prices correlated with the country's terms of trade). ${ }^{22}$ At any rate, the relative advantage of a financial dedollarizing strategy should not be taken for granted.

\section{Financial dollarization: The drivers}

As noted, in order to counter financial dollarization one first needs to understand the factors that determine its persistence. A quick survey of the literature indicates that dollarization persistence (or hysteresis) have been attributed, over the years, to one or more of the following causes:

i. Long-lasting inflationary memories in economies with a track record of monetary mismanagement (e.g., Savastano, 1996),

ii. The use of the dollar as unit of account in inflationary economies with high nominal stability (Guidotti and Rodriguez, 1992),

iii. Portfolio (hedging) considerations that point at the relatively stable real exchange rates and the incomplete adjustment of nominal interest rates as a source of demand for dollar assets (Thomas, 1985; Ize and Levy Yeyati, 2000),

iv. The time inconsistency problem of a dollar-indebted government tempted to repudiate its debt ex-post through devaluation and inflation (Calvo and Guidotti, 1990);

\footnotetext{
${ }^{22}$ One could argue that, in the limit, the distinction between indexed dollar instruments and local currency instruments is rather blurred, particularly as the index of choice increases its correlation with the country's RER. However, the key distinction between local and indexed foreign currency instruments lies in the
} 
v. Currency-blind regulations that introduce market distortions due to imperfect risk pricing:

a. Explicit or implicit financial safety nets such as deposit insurance or lender of last resort policy (Broda and Levy Yeyati, 2002),

b. "Too-many-to-fail" considerations: Implicit debtor guarantees derived from the social and political costs of massive bankruptcies (Burnside et al., 1999), and

c. Currency-blind or dollar-friendly financial regulation as a result of a signaling problem (as in the "peg trap" described in De la Torre et al., 2002). ${ }^{23}$

The first two explanations are linked to the currency substitution approach to dollarization that stresses the negative link between the demand for local currency and inflation in the first case, and between nominal instability and the choice of the unit of account, in the second. As such, they are relevant to the purpose of this project inasmuch as currency substitution influences the currency composition of savings. The phenomenon of currency substitution, however, appears to be relatively minor even in those Latin American countries that exhibit high financial dollarization levels, as wages and most goods and services are denominated in the local currency. ${ }^{24}$ On the other hand, recent empirical studies find that the inflation pass-through is highly endogenous, depending, among other things, on past inflation. ${ }^{25}$ This, combined with the low passthrough coefficients exhibited by Latin American countries in the aftermath of recent currency collapses, suggests that currency substitution and, in particular, dollar pricing, may have been overstated for the region.

degree of exogeneity of the latter's index, that mitigates the moral hazard that is at the root of peso problem.

${ }^{23}$ In policy circles of dollarized economies dollarization is often attributed to mere habit, an argument partially related to the switching costs story in Guidotti and Rodriguez (inasmuch as the sight deposits may provide liquidity servicies and therefore be influenced by the unit of account of current transactions). In addition, monetary authorities have been promped to introduce (or facilitate) foreign currency deposits due to the need to limit capital flight and to protect banks from runs induced by changes in the currency composition of local portfolios during inflationary episodes.

${ }^{24}$ Typical exceptions are big-ticket items (e.g., real estate) and specific cases such as tariffs of privatized utilities in Argentina.

${ }^{25}$ See, e.g., Goldfajn and Werlang (2000). 
The last three groups of arguments in the list, inspired by the prudential implications that underscore the present agenda, are instead directly linked to the view of dollarization as an asset substitution phenomenon and, as such, deserve a closer look.

\section{The portfolio argument}

Ize and Levy Yeyati (1998)'s portfolio approach stresses as the main drivers of financial dollarization of resident investors and borrowers are the volatilities of real cash flow of assets in each currency (measured in units of the consumption basket, in the first case, and the production mix, in the second), which in turn depend on the volatility of inflation (for peso assets) and real depreciation (for dollar assets). This approach leads to one important implications for the design of dollar-competing instruments: ceteris paribus, CPI-indexed deposits should generally dominate dollar deposits, as they minimize (and, if perfectly indexed, eliminate) real return volatility. ${ }^{26}$ The paper presents two additional conclusions that bear relation with the objective of the project. On the one hand, policies that target a stable real exchange rate to preserve competitiveness favor financial dollarization (suggesting instead a combination of floating exchange rates with inflation targeting). On the other, economies with high pass-through coefficients (either because of their very open nature, or due to widespread dollar pricing as a remnant of past inflation episodes) will exhibit higher dollarization ratios (in the limit, full dollar pricing eliminates the volatility of dollar assets).

The implicit assumptions made by this argument, notably the assumption that depositors measure the risk / return characteristics of financial assets in terms of the local consumption basket, point directly at the distinction between internal and external

\footnotetext{
${ }^{26}$ Note that the same is true for the borrowing firm to the extent that the CPI is closely correlated with the firm's profits. The non-trivial discussion of the choice of the proper index is resumed below. Two additional qualifications seem warranted. First, off-shore deposits (or dollars "under the matress") are not directly comparable to indexed deposits in local banks due, e.g., to default and confiscation risk. Second, the fact that indexation is least accurate precisely in periods of high nominal volatility detracts considerably from the attractiveness of indexed assets, a concern that should be properly addressed in the design of the instrument.
} 
markets. ${ }^{27}$ More precisely, in the presence of risk aversion, for given exchange rate and inflation volatilities in group of countries, instruments denominated in the local currency will look relatively more attractive to local savers (borrowers), as they will mirror their stream of future consumption (income) more closely. As a result, it would be easier (or at least less costly) to introduce local currency instruments in domestic markets than abroad. $^{28}$

The argument can be readily applied to the debate on dollarization of public debt. Countries with more limited domestic savings would tend to exhibit a larger share of foreign currency-denominated external debt. Indeed, there is some indirect evidence of a link between the currency of denomination and the financial center where it is issued, and some indication that past debt dedollarization processes have been driven by a deepening of the domestic markets. ${ }^{29}$

Similarly, developing countries with a sizeable stock of foreign assets are the most likely to profit from the development of local markets, once the underlying reasons for capital flight are properly addressed. It also yields implications on the nature of the desired target for the introduction of local currency instruments. In particular, while most of the financial dollarization literature has focused on deposit funding, special consideration should be given to the demand of local institutional investors that is likely to be the first to demand local currency securities under a successful dedollarization strategy. ${ }^{30}$

Finally, the distinction between internal and external markets brings up a number of specific financial and prudential consideration in the process of tailoring the new securities to the potential foreign investors (for example, the design of mechanisms to

\footnotetext{
27 This distinction was originally made by Thomas (1985) in a two-country setup.

${ }^{28}$ The argument, however, ignores other non-financial income of domestic savers. If this income is negatively correlated with the real exchange rate, one should expect savers to diversify by investing in foreign currency assets. This CCAPM-type of argument, however, seem at odds with the very limited international diversification observed in practice.

${ }^{29}$ See, e.g., Bordo et al. (2002). In a related paper, Claessens et al. (2003) find that the dollarization ratio of (internal plus external) government bonds is negatively related with the size of domestic financial markets.

${ }^{30}$ The Chilean case provides an example of the crucial role played by institutional investors in the development o flocal currency capital markets, as virtually all peso-denominated debt (including that not issued by the sovereign) is in the portfolios of private pension funds.
} 
split exchange rate risk from sovereign risk), and the trade-off between excessive local (and, particularly, fiscal) exposure of institutional investors and the need to channel domestic savings domestically in an efficient way in order to avoid excessive exchange rate exposure.

\section{The time inconsistency argument}

The time inconsistency argument relies on the fact that nominal debt gives the government the temptation to inflate away the real burden of the debt. If the government has no way to commit to low inflation, expectations that anticipate this behavior lead to the familiar inflation bias, which increases the loss function of a government that actually cares about (ex-post) inflation. ${ }^{31}$ Focusing on the public debt issue, Calvo and Guidotti (1990) argue in favor of partial dollar indexation as a way to reduce the inflation bias. ${ }^{32}$

For the purpose of our study, the time inconsistency story, while focused on the currency of denomination of public debt, leave a number of questions unanswered. In particular, it does not fully explain why, in practice, some countries are more subject to the inflation bias than others, relying perhaps too strongly on the expediency of a poor track record. If the cost-benefit analysis of the repudiation-by-inflation decision hinges on the costs of servicing the debt, for a given repudiation cost, low repudiation expectations (low rates) will be self-fulfilling as they tilt the balance away from repudiation, while high rates would do the opposite. Thus, a poor track record would be associated with high rates, high probability of repudiation, and high inflation bias. Moreover, if the government cares about inflation, a high inflation bias would dissuade a government from issuing peso debt if inflation concerns dominate prudential concerns related to real exchange rate

\footnotetext{
${ }^{31}$ Note that, according to this argument, CPI indexation should eliminate the incentive to monetize and solve the problem. I come back to the relative advantages of dollar vis a vis CPI indexed debt in international markets later in the paper.

${ }^{32}$ They argue that full indexation may not necessarily be optimal since in that case a government facing an expendiutre shock would not be able to apply the inflation tax on debt to smooth out the distorting effect of changes in other conventional taxes.
} 
exposure. ${ }^{33}$ Thus, the original sin motive could be interpreted as a deliberate choice from the issuer, rather than as a missing market. Then again, a poor track record is, at least from a policy perspective, a rather unsatisfying answer to the key question, namely, what determines that one country enjoys one equilibrium or suffers the other, particularly in a context of forward looking investors. ${ }^{34}$

On the other hand, this approach does not (nor is its aim to) address the issue of private liability dollarization. In principle, dollarized public debt may indeed facilitate local currency borrowing as agents could perceive the fiscal cost of a devaluation as a guarantee that inflationary policies would not be pursued. While the time inconsistency argument could be extended to the case of a local currency-indebted private sector if the government perceive private debt-dilution as expansionary (or welfare enhancing), it seems likely that the underlying reasons have to be searched for somewhere else.

\section{The currency-blind regulation argument}

This strand of explanations points to market imperfections related with the regulatory framework. The case of full (and currency-blind) deposit insurance illustrates the argument in Broda and Levy Yeyati (2000). If the insurance is activated in the event of a sharp devaluation (due to its correlation with banks' solvency), dollar depositors are provided full protection against exchange rate risk in the worst states of nature at the expense of the deposit insurance agency (and, ultimately, of depositors in both currencies, if the insurance is fully funded by bank contributions, or of taxpayers, if it is underfinanced). Thus, banks do not factor in the higher cost of dollar funding in bad states of nature, effectively reducing the peso-dollar spread and making dollar assets relatively more attractive.

\footnotetext{
${ }^{33}$ In the standard Calvo and Guidotti's (1990) model, purchasing power parity holds so that dollar and CPIindexed debt are indistinguishable. As a result, real exchange rate shocks and, accordingly, exchange rate exposure consideration, are ignored in this early literature.

34 The rapid rebound of capital inflows in many countries that faced debt crisis and even default relatively recently casts doubt on the relevance of track records to determine accessibility to international markets. However, none of these countries have attempted to reverse the dollarization of its external debt.
} 
The implicit debtor guarantee argument introduces a quota of realism by addressing the time inconsistency of the government's decision regarding its involvement in the resolution of a crisis, given its widespread negative externalities. More concretely, in line with a standard Samaritan's dilemma, the government may find it ex-post optimal to intervene in favor of dollar debtors if a nominal devaluation threatens to precipitate massive bankruptcies and a systemic financial crisis, with the associated costs in terms of social distress and loss of value. ${ }^{35}$ Thus, in contrast with the previous argument, debtors (and, for that matter, banks) may not default even after a sharp devaluation. Debtors that anticipate this possibility may be lured by what they judge to be artificially low dollar lending rates. ${ }^{36}$ Again, the problem is linked to the mispricing of exchange rate risk, in this case due to an implicit subsidy to dollar lending that is eventually financed through taxes or through the partial confiscation of deposits (as was the case recently in Argentina). The imperfection is not dissimilar to the too-big-to-fail problem, except that in this case is compounded by the fact that the victims of the devaluation, while not necessarily large, are just too many to be ignored (hence the too-many-to-fall label). The political economy if this decision, while relatively simple, is possibly the key factor in driving the massive debtor bailouts that follow a currency crisis in a financially dollarized economy. ${ }^{37}$ Since there are no credible ways to prevent the government from undertaking such a massive transfer of wealth, it follows that preemptive actions (such as penalties for dollar intermediation) should be introduced ex-ante to correct this imperfection.

Finally, the signaling argument was originally proposed for financial dollarization for the particular case of pegs. In a nutshell, the story stresses the fact that the government's quest to build confidence on the sustainability of a fixed parity is at odds with distinguishing assets across currencies (for example, for prudential considerations).

\footnotetext{
${ }^{35}$ Note that this induces an externality even if the government does not intervene ex - post, since the cost of massive bankruptcy is distributed over the entire population and, thus, not fully internalized by the borrower.

${ }^{36}$ Indeed, the experience of recent currency crisis such as those in Mexico, Brazil, and Argentina provide strong support to this type of beliefs.

${ }^{37}$ In a rational expectations context, however, the mere anticipation of these transfers should deter domestic savers from keeping their funds on-shore. However, the political economy reasons explain why savers are not necessarily the net losers, as in practice the transfer is conducted through the relatively obscure expedient of long-term public debt issuance.
} 
In principle, this argument could be taken as extending that in Calvo and Guidotti (1990) to the private economy by exploiting balance sheet effects. Indeed, De la Torre et al. (2002) go a step further in that direction to point out that financial dollarization may not only be a natural consequence of this signaling problem, but also a constitutive ingredient of a peg strategy that borrows credibility from the existence of prohibitively high exit cost, of which the balance sheet effects derived from financial dollarization are a key component, thus overcoming the temptation to devalue. As such, financial dollarization could be interpreted as a deliberate action or, as the authors put it, "as a high-stakes strategy to overcome a weak currency problem."

\section{Courses of action}

Many of the arguments previously discussed tend to be analytical and beg a more rigorous empirical exploration. In addition, no Latin American country has in recent years launched an explicit strategy to reduce dollarization, and most of the attempts on this front were at best half-hearted and, in some cases, misguided. These attempts, however, provide information as to the scope and effectiveness of alternative measures and on the impact of the macreoeconomic context on the evolution of the use of the local currency in its different roles. As such, they should be considered very carefully.

As a preliminary benchmark, the discussion highlights two main fronts on which a potential dedollarizer should center his efforts. On the one hand, there is the question of incentives, linked to the risk mispricing problem described above, which may stimulate excessive dollarization or explain its persistence. This entails mainly the revision and adaptation of existing prudential regulation, in a way that eliminates distortions that hamper the use of the local currency for financial transactions minimizing the costs in terms of financial desintermediation or distortions elsewhere. On the other hand, there are a number of issues related with the design of local currency instruments so as to create and enhance the local currency substitutes for dollar assets, and the development of 
(mainly domestic) markets for these instruments. The following list summarizes the main questions to be explored.

\section{The Stick: Prudential Regulation}

Standard prudential best practices (for both the banking sector and other financial markets) as well as those actually implemented in financially dollarized economies, typically address currency imbalances at the bank level through limits on open currency positions, but tend to be silent on the credit risk associated with dollar loans to non-dollar producers.

In addition, in those economies where dollar intermediation is allowed, regulatory frameworks are often currency-blind, possibly due to its short-term benefits of deeper financial intermediation. Examples abound. In an extensive survey of deposit insurance around the world, Garcia (1999) finds that less than twenty out of seventy-two countries with bi-currency financial systems discriminate against foreign-currency deposits by excluding them from the insurance coverage. Another way in which prudential norms may benefit the dollar is through unremunerated reserve requirements. Since the cost associated with the holding of liquid reserves is proportional to the funding cost in each currency, the presence of a positive peso-dollar spread punishes peso intermediation. ${ }^{38}$

Less straightforward is the effect of general liquidity requirements on the choice of denomination. The fact that reserves are used indistinctly in the case of a run detracts from the benefits of investing in pesos. The limiting case of currency-specialized banks illustrate this problem: inasmuch as peso deposits are of a transactional rather than a investment nature, peso banks, unlike dollar banks, should be less vulnerable to sudden changes in devaluation expectations. Bi-currency banks, instead, are likely to exhaust their liquidity to cope with a speculative run, triggering a preventive run of otherwise

\footnotetext{
${ }^{38}$ The argument can be readily extended to the more common case of under-remunerated reserve requirements. Note that, inasmuch as the requirement is binding, even if reserves are remunerated at a market rate, from the banks' standpoint the cost of holding excessive liquidity would still be proportional to the funding costs in each currency.
} 
stable peso deposits. Moreover, if instead peso depositors respond by dollarizing within the banking sector, the need to adjust the denomination of bank liquid reserves would induce a strong demand for dollars that would only deepen existing devaluation pressures (and the chances that the central bank simply relax its requirements).

At any rate, by inducing a disproportionate tax on local currency intermediation or by failing to fully price exchange rate risk, prudential norms tend to generate a contingent aggregate liability that ultimately is assumed by the public sector in case of a sudden realignment of the real exchange rate.

However, the use of prudential norms to limit the currency exposure at the firm level points directly to the trade-off between lower credit risk and reduced access to financing by non-dollar earnings. While exporters (and other dollar earners) should not be affected by this prudential tightening (and, indeed, should be benefited as dollar savings are freed from other uses), other borrowers with non-dollarized incomes (including producers of non-tradables and most individuals) will see their access to financing suddenly limited. ${ }^{39}$ As a result, a reasonable concern about the availability of sources of peso financing may lead policymakers to prefer an intermediate stance, raising the cost of dollar funding for the latter group without making it prohibitively costly.

This leads to a second trade-off, namely, between strict quantitative limits (such as maximum loan dollar share per bank, or restrictions on the application of dollar funds) and proportional tax-like measures (such as higher risk weights or higher liquidity requirements on dollar assets). The question also applies to the prudential treatment of foreign vis à vis domestic borrowing, still subject to debate. ${ }^{40}$ In both cases, the time inconsistency problem is central to the analysis. As noted, even if prudential norms are revised so as to eliminate their dollarization bias, one still has to deal with the perception of implicit guarantees generated by widespread financial dollarization, which, when

\footnotetext{
${ }^{39}$ Hence, the emphasis of this paper on the importance of a two-sided strategy that fosters local currency intermediation at the same time (and even before) the new norms are phased in.
} 
anticipated, lead to the underestimation of exchange rate risk. Dollar mortgage loans provide one telling example: Is it reasonable to expect the government not to step in when a sudden depreciation of the local currency places a large fraction of the population at the risk of losing their homes? But, if the answer is negative, how can prudential norms credibly dissuade individuals from borrowing in dollars unless a quantitative limit on dollar lending is introduced? At any rate, while policy credibility is still an issue for debate, time inconsistency considerations may argue in favor of (at least some) quantitative cap on exchange rate exposure, particularly in those countries that offered exchange rate guarantees in the past. ${ }^{41}$

In sum, given the positive correlation between exchange rate risk and credit risk in financially dollarized economies, the value of any safety net (and, in turn, its fiscal cost) is typically higher for dollar instruments and has to be priced accordingly. Thus, in order to avoid cross-subsidies, exchange rate risk exposure should be factored in the provision of insurance. Moreover, implicit insurance and other time inconsistency problems may render market-based measures (higher risk weights, larger bank contributions to the insurance fund) ineffective, justifying a move to quantitative exposure limits.

With this in mind, a revision of safety nets and regulations deserve careful attention in the context of any dedollarization strategy. A number of aspects (some new, some already in place in many countries) deserve careful consideration. ${ }^{42}$

Deposit insurance schemes can be amended in a number of ways. First, as in many countries, it may be specialized to include only peso bank deposits, (alternatively, deposit insurance may be provided up to a maximum local currency amount per claimant independently of the currency of denomination of the original deposit). In addition, for a

\footnotetext{
${ }^{40}$ For example, liquidity requirements on foreign borrowing has been advocated invoking prudential reasons (and the need to avoid a differential treatment that stimulates off-shorization), but has been resisted as a barrier to capital mobility.

${ }^{41}$ Argentina is a good example of the latter: all dollar debt was converted to CPI-indexed pesos after the devaluation. Moreover, most mortgages were soon thereafter re-indexed to a (much more stable) salary index.

${ }^{42}$ The discussion of prudential measures below assumes the existance of a limit on net foreign exchange positions at the bank level.
} 
given insured amount, bank contributions could be higher for dollar deposits. As noted, however, the value of this measures lies in their impact on the marginal funding cost to the bank rather than in their disciplining effect on depositors, as in practice cases in which depositors suffer a substantial loss as a results of a bank failure are the exception rather than the rule. ${ }^{43}$

Along the same lines, liquid asset requirements can differ according to the denomination of bank liabilities, with greater shares associated with dollar liabilities. As before, inasmuch as bank liquidity is used to cope with deposit withdrawals in either currency, higher liquidity requirements can address banks' exposure to a deposit run only partially. Their main impact, again, would come from the marginal cost of dollar funding.

Exchange rate-related credit risk could be considered in the computation of capital adequacy ratios, for example, by raising weights for dollar loans to non-dollar earners. While the precise implementation of this measure (particularly, the way in which a borrower is assigned a "dollar earner" status) is not trivial, the criterion should be aimed at controlling potential currency imbalances. Therefore, extra weights could be a function of the ratio between dollar debt service and dollar income generated in the recent periods, much in the same way as dollar debt over exports is taken as a proxy of the capacity to pay of a sovereign. As a result, one should expect to see dollar lending rates increase with the "tradability" of the borrower. Assuming that a profit maximizing bank will translate the higher marginal funding cost directly to lending rates, the authorities may still face the problem of the contestability of the "export earner" status, and banks may face claims of discrimination. If those cases in which a market-based pricing mechanism cannot be implemented, more drastic, quantitative limits on foreign currency lending, based on the export income of the borrower, may be preferable.

\footnotetext{
${ }^{43}$ This is important, since both here and in the discussion of other prudential ratios below, the expected impact of the proposed revisions comes from its incidence on relative intermediation costs in each currency rather than from a target coverage level.
} 
High bank liquidity requirements have been increasingly favored by financially dollarized economies as a way to compensate for the limited capacity of the central bank to fulfill its role as lender of lat resort in the event of a systemic run. However, recent crisis episodes in Argentina and Uruguay attest to the limits of using the liquidity buffer to contain massive deposit outflows. Indeed, if with Argentina we learned that the evolution of deposits differ according to type (with transactional deposits exhibiting significantly more stability), in Uruguay the authorities correctly exploited this difference ex-post by suspending convertibility of (mostly dollar-denominated) time deposits and assigning the remaining systemic liquidity to back demand and savings accounts, freezing the run while preserving the payments system.

This principle could be readily applied ex-ante, without the need to resort to a dual system of peso transactions banks and dollar investment banks as sometimes proposed, by specializing the use of bank liquidity. A limit on the amount of liquidity that could be used to meet a run on time deposits or, more specifically, a stop-loss clause for time deposits that suspends their convertibility automatically (for example, once the liquidity ratio reaches a certain threshold) could reassure transaction depositors that bank liquidity would not be exhausted by the time they decide to make use of their funds. Note that a stop-loss clause is only different from early intervention by the bank supervisor in that it is announced ex-ante (leaving out discretionality and reducing time inconsistency) and, as a result, provides demand depositors with an explicit guarantee. ${ }^{44}$

At any rate, this scheme could be readily used in a proactive way to stimulate the use of the local currency, for example the liquidity associated with peso deposits is earmarked to meet withdrawals by peso depositors or, more drastically, by inverting the cross subsidy introducing a stop-loss clause on dollar (but not peso) deposits in order to reassure peso depositors that bank liquidity would not be exhausted by the time they decide to use their funds. The same can be said about other norms mentioned above. ${ }^{45}$

\footnotetext{
${ }^{44}$ Many other alternative ways of earmarking bank liquidity can be thought of to the same effect.

${ }^{45}$ Chile's unremunerated reserve requirements on foreign borrowing can be readily interpreted in this way.
} 
It goes without saying that all of these measures merit a rigorous analysis and, as such, are intimately related to the current context of individual economies. Moreover, common to all of them is the general time inconsistency concern that plagues many prudential recommendations. How can a restricted deposit insurance scheme credibly rule out the possibility of an exchange rate guarantee once the short-run impact of a devaluation is imminent? How can an automatic reprogramming of time deposits be implemented (per force, through the intervention of the regulatory authority) without impinging on the rest of the financial system?

Having said that, all of them share the aim to introduce a peso-dollar wedge in intermediation costs to incorporate externalities previously swept under the rug of contingent fiscal liabilities. As such, the magnitude of this wedge should be based on a clear understanding of the costs of these externalities. More precisely, while dollar funding could be judged to be artificially inexpensive in many cases, the risk of excessive real exchange rate exposure has to be weighted against the benefits of a deeper dollarbased intermediation reaped in good times. Conversely, the net benefits of a dedollarization strategy depend crucially on the success in introducing alternative peso instruments to reroute savings within the domestic market. To this I turn next.

\section{The carrot: Saving and lending in pesos}

Perhaps the main deterrent of a dedollarization policy is the fear of impending desintermediation: how to address the potential problem of underfinancing of the nontradable sector if dollar lending to these sectors is limited or banned by regulation, and long-term local currency markets do not materialize? Thus, while the prudential approach discussed in the previous section tends to diminish the incentives for dollar vis $\grave{a}$ vis peso intermediation, it needs to be complemented with the introduction of peso instruments that are attractive for both savers and borrowers.

A key objective of a dedollarization agenda is then to assess the conditions for a successful introduction of those instruments, based on past experiences and on current 
country-specific considerations. For example, the Chilean and Israeli precedents suggest that CPI-indexed assets may have good chances to compete with dollar assets, and eventually reduce financial dollarization. However, comparable experiences in Argentina and Uruguay in the late 70s ended with a compulsory de-indexation as inflation picked up. Argentina provides yet another example of the type of contractual uncertainty that conspires against the use of indexation as a means to deepen and lengthen the peso market: in 2002, dollar mortgages were pesified and indexed to the CPI, only to be reindexed to the much lower wage index a few months down the road. Thus, indexation, rather than limiting the government's temptation to inflate, can be the victim of contractual fragility. Interestingly, though, the same can be said as dollarization as a disciplinary mechanism, as many compulsory conversions in Latin American countries in the past, and the recent Argentine experience attests. At any rate, institutional credibility (both fiscal, monetary and contractual) is essential for indexation to succeed.

The creation of liquid peso markets comprises not only (indexed and non-indexed) local currency deposits and loans. Alternative non-bank sources of local currency financing are likely to become increasingly important in the aftermath of systemic banking crises (as in the case of Mexico post-Tequila). Aspects to be considered in this regard include the development of deep forward markets (incipient or inexistent in many emerging economies with allegedly floating regimes) that allow firms' to hedge exchange rate risk without keeping large dollar holdings, as well as the introduction of non-bank products such as fiduciary funds and specialized financial institutions.

How should peso instruments be introduced? The question encompasses several issues. First, there is the question of indexed vs. non-indexed instruments. While indexation is clearly a prime candidate in the context of a dedollarization strategy, as the experiences of Chile and Israel suggest, it is not the only way to go. At any rate, in this paper it is 
advocated as a way to lengthen the maturity of financial contracts, rather than the depth of the markets. ${ }^{46}$

Indexation entails a tradeoff between market depth (which calls for a minimum number of indexes) and the correlation between the index and the cash flows faced by individual investors and borrowers to minimize volatility (which calls for several customized indexes). Thus, while CPI-indexed assets may be an attractive catch-all option for small savers, they may suffer from inadequate demand on the borrowers' side. Conversely, assets that follow the evolution of specific prices or sectors may look opaque or subject to manipulation to the public. The point is also related to the need to match indexed assets and liabilities at the bank level, which requires a wide acceptance of indexed borrowing, where standard CPI-indexation may be insufficient. In addition, indexation leads to (and can be fostered by) the need to adapt monetary policy, for example, through the issuance of public short-term indexed paper that serves as a benchmark for the computation of an indexed yield curve (in this case, a single index policy is definitively a plus). Finally, there is the always contentious issue of the potential spillover of financial indexation to non-financial contracts and its implications on monetary policy.

Irrespective of the willingness of the public to adopt the new peso instruments, a dedollarization strategy is likely to face a serious liquidity problem at the start-up stage, as markets for local currency securities, at least in the short run, will not be able to profit from the existence of fully developed international markets for foreign-currency emerging market paper. ${ }^{47}$ In this regard, regulations governing the financial choices of institutional investors may be aimed at increasing the appetite for peso assets, to the extent that it does not detract from their capacity of these investors to fulfill its role. For example, private pension funds could be used, as they are in many countries, to create a non-speculative demand for high quality long-term peso paper to the extent that a liquid market for these paper exists.

\footnotetext{
${ }^{46}$ Interestingly, financial dollarization in convertible Argentina did not provide a significant lengthening of bank deposits, suggesting, in line with this paper's emphasis on non-bank finacing, that longer-term funding has to be seeked elsewhere.

${ }^{47}$ This also applies to equity markets, currently hampered by low liquidity and outdated legal institutions.
} 
Assuming that a dedollarization strategy is ultimately successful, we still has to face the transition problem: how to finance the non-tradable sector if savings in the local currency are, as expected, slow to take off? In addition to transition considerations (the speed of the introduction of dedollarizing measures to avoid a credit crunch), there may be longrun concerns arising from the credit bias that a dedollarization strategy may introduce between dollar-earners and the rest, particularly if dollar lending is made more costly (or directly banned) for the latter.

\section{Final remarks}

The previous outline presents the contents of a research agenda that is long overdue, particularly in light of recent developments in financial markets. Their conclusions should inform important aspects of exchange rate and monetary policy, and should help adapt existing prudential regulations to the emerging market context. Whereas financial dollarization has become a relevant issue for emerging markets as a whole, a solid background that helps avoid well-intentioned but ultimately misguided policy experiments is still lacking. Providing policymakers with such a background is the objective of this agenda.

At the onset, any dedollarization strategy should entail a two-way approach. On the one hand, a revision of prudential regulation to address ex-ante the externalities associated with financial dollarization that favor the use of the dollar. The resulting increase in dollar funding cots (the stick) will certainly have negative real effects and will be destabilizing for the financial sector unless new measures are phased in pari passu with the introduction and promotion of peso instruments to channel the currency switch (the carrot).

This paper tried to summarize some of the recurrent issues that arise whenever financial dollarization is discussed and suggestions as to how they could be dealt with, but left out 
many others (including some that may arise as agenda specializes to the case of individual countries). Needless to say, any successful dedollarization strategy should be accompanied by sound monetary policies, as the Chilean and Israelian experience attest. However, as witness the Argentine convertibility, the Uruguayan crawling peg or the Peruvian managed float, sound monetary policies are necessary but not sufficient. Hence, a proactive agenda with specific measures aimed at strengthening the local currency is needed to complement conducive macro policies. 


\section{REFERENCES}

Bordo, Michael, Christopher Meissner and Angela Redish (2002) How “Original Sin" was Overcome: The Evolution of Externa Debt Denominated in Domestic Currencies in the United States and the British Dominions 1800-2000, mimeo.

Burnside, Craig, Martin Eichenbaum and Sergio Rebelo (1999) Hedging and Financial Fragility in Fixed Exchange Rate Regimes NBER Working Paper No. 7143.

Calvo Guillermo (2000) The Case for Hard Pegs in the Brave New World of Global Finance, mimeo University of Maryland.

Calvo, Guillermo and Carmen Reinhart (2000) Fear of Floating, NBER Working Paper No. 7993.

Calvo, Guillermo and Carlos Vegh (1997) From Currency Substitution to Dollarization and Beyond: Analytical and Policy Issues, in Guillermo Calvo, Essays on Money, Inflation and Output, Cambridge, MA: MIT Press.

Calvo, Guillermo and Carlos Vegh (1992) Currency Substitution in Developing Countries: An Introduction, Revista de Análisis Económico, Vol. 7, pp.3-28.

Calvo, Guillermo and Pablo Guidotti (1990) Credibility and nominal debt: exploring the role of maturity in managing inflation. IMF Working paper: WP/89/73.

Claessens, Stijn, Daniela Klingebiel and Sergio Schmukler (2003) "Government Bonds in Domestic and Foreign Currency: The Role of Macroeconomics and Institutional Factors," mimeo, The World Bank.

De la Torre, Augusto, Eduardo Levy Yeyati and Sergio Schmukler (2002a) Beyond the Bipolar View: The Rise and Fall of Argentina’s Currency Broad. Economía, forthcoming. 
De la Torre, Augusto, Eduardo Levy Yeyati and Sergio Schmukler (2002b) Financial Globalization: Unequal Blessings. International Finance, forthcoming.

Giovannini, Alberto and Bart Turtleboom (1994) Currency Substitution, in Frederick van der Ploeg, ed. Handbook of International Macroeconomics, Blackwell Publishers, Cambridge, MA, pp. 39-436.

Guidotti, Pablo and Carlos Rodriguez (1992) Dollarization in Latin America: Gresham's Law in Reverse? IMF Staff Papers, Washington: International Monetary Fund, Vol. 39, pp.518-544.

Haussman, Ricardo (1999) Should There Be Five Currencies or One Hundred and Five? Foreign Policy.

Ize, Alain and Eduardo Levy-Yeyati (2000) Financial Dollarization. Journal of International Economics, forthcoming. Available at www.utdt.edu/ ely.

Sahay, Ratna and Carlos Vegh (1997) Dollarization in Transition Economies: Evidence and Policy Implications, The Macroeconomics of International Currencies, Theory, Policy and Evidence, edited by Paul Mizen and Eric J.Pentecost, Brookfield, Vt:Edward Elgar, 1996.

Savastano, M.A. (1996) Dollariztion in Latin America: Recent Evidence and Some Policy Issues, IMF Working Paper, 96/4, Washington: International Monetary Fund, January 1996.

Thomas, L.R. (1985) Portfolio Theory and Currency Substitution, Journal of Money, Credit, and Banking, Vol. 17, pp.347-357. 


\section{Universidad Torcuato Di Tella, Business School Working Papers}

\section{Working Papers 2003}

NN16 "Business Cycle and Macroeconomic Policy Coordination in MERCOSUR"

Martín Gonzalez Rozada (UTDT) y José Fanelli (CEDES).

No15 "The Fiscal Spending Gap and the Procyclicality of Public Expenditure"

Eduardo Levy Yeyati (UTDT) y Sebastián Galiani (UDESA).

No14 "Financial Dollarization and Debt Deflation under a Currency Board"

Eduardo Levy Yeyati (UTDT), Ernesto Schargrodsky (UTDT) y Sebastián Galiani (UDESA).

№13 " ¿ Por qué crecen menos los regímenes de tipo de cambio fijo? El efecto de los Sudden Stops", Federico Stuzenegger (UTDT).

№12 "Concentration and Foreign Penetration in Latin American Banking Sectors: Impact on Competition and Risk", Eduardo Levy Yeyati (UTDT) y Alejandro Micco (IADB).

№11 "Default 's in the 1990's: What have we learned?",

Federico Sturzenegger (UTDT) y Punan Chuham (WB).

№10 "Un año de medición del Indice de Demanda Laboral: situación actual y perspectivas",

Victoria Lamdany (UTDT) y Luciana Monteverde (UTDT)

N'09 "Liquidity Protection versus Moral Hazard: The Role of the IMF",

Andrew Powell (UTDT) y Leandro Arozamena (UTDT)

№8 "Financial Dedollarization: A Carrot and Stick Approach", Eduardo Levy Yeyati (UTDT)

No07 "The Price of Inconvertible Deposits: The Stock Market Boom during the Argentine crisis",

Eduardo Levy Yeyati (UTDT), Sergio Schmukler (WB) y Neeltje van Horen (WB)

NN06 "Aftermaths of Current Account Crisis: Export Growth or Import Contraction?",

Federico Sturzenegger (UTDT), Pablo Guidotti (UTDT) y Agustín Villar (BIS)

No5 "Regional Integration and the Location of FDI",

Eduardo Levy Yeyati (UTDT), Christian Daude (UM ) y Ernesto Stein (BID)

N04 "A new test for the success of inflation targeting",

Andrew Powell (UTDT), Martin Gonzalez Rozada (UTDT) y Verónica Cohen Sabbán (BCRA)

No03 "Living and Dying with Hard Pegs: The Rise and Fall of Argentina's Currency Board",

Eduardo Levy Yeyati (UTDT), Augusto de la Torre (WB) y Sergio Schmukler (WB)

No02 "The Cyclical Nature of FDI flows",

Eduardo Levy Yeyati (UTDT), Ugo Panizza (BID) y Ernesto Stein (BID) 
№1 "Endogenous Deposit Dollarization",

Eduardo Levy Yeyati (UTDT) y Christian Broda (FRBNY)

\section{Working Papers 2002}

№15 "The FTAA and the Location of FDI",

Eduardo Levy Yeyati (UTDT), Christian Daude (UM ) y Ernesto Stein ( BID)

No14 "Macroeconomic Coordination and Monetary Unions in a N-country World: Do all Roads

Lead to Rome?"

Federico Sturzenegger (UTDT) y Andrew Powell (UTDT)

№13 "Reforming Capital Requirements in Emerging Countries"

Andrew Powell (UTDT), Verónica Balzarotti (BCRA) y Christian Castro (UPF)

№12 "Toolkit for the Analysis of Debt Problems", Federico Sturzenegger (UTDT)

№11 "On the Endogeneity of Exchange Rate Regimes",

Eduardo Levy Yeyati (UTDT), Federico Sturzenegger (UTDT) e lliana Reggio (UCLA)

№10 "Defaults in the 90's: Factbook and Preliminary Lessons", Federico Sturzenegger (UTDT)

No09 "Countries with international payments ' difficulties: what can the IMF do?"

Andrew Powell (UTDT)

NN08 "The Argentina Crisis: Bad Luck, Bad Management, Bad Politics, Bad Advice",

Andrew Powell (UTDT)

N07 "Capital Inflows and Capital Outflows: Measurement, Determinants, Consequences",

Andrew Powell (UTDT), Dilip Ratha (WB) y Sanket Mohapatra (CU)

No06 "Banking on Foreigners: The Behaviour of International Bank Lending to Latin America, 1985-2000",

Andrew Powell (UTDT), María Soledad Martinez Peria (WB) y Ivanna Vladkova ( IMF)

No05 "Classifying Exchange Rate Regimes: Deeds vs. Words"

Eduardo Levy Yeyati (UTDT) y Federico Sturzenegger (UTDT)

NN04 "The Effect of Product Market Competition on Capital Structure: Empirical Evidence from the

Newspaper Industry", Ernesto Schargrodsky (UTDT)

N03 "Financial globalization: Unequal blessings",

Augusto de la Torre (World Bank), Eduardo Levy Yeyati (Universidad Torcuato Di Tella) y Sergio

L. Schmukler (World Bank)

N02 "Inference and estimation in small sample dynamic panel data models",

Sebastian Galiani (UdeSA) y Martin Gonzalez-Rozada (UTDT)

№1 "Why have poverty and income inequality increased so much? Argentina 1991-2002",

Martín González-Rozada, (UTDT) y Alicia Menendez, (Princeton University). 